\title{
- SATYSFAKCJA PACJENTÓW MAKROREGIONU LUBELSKIEGO Z USEUG WYBRANYCH PORADNI SPECJALISTYCZNYCH ŚWIADCZEŃ ZDROWOTNYCH
}

\section{LUBLIN MACROREGION RESIDENTS' SATISFACTION WITH MEDICAL SERVICES FROM SELECTED SPECIALIST CLINICS}

\author{
Olga Dąbska, Zbigniew Tarkowski, Ewa Humeniuk, Joanna Monastyrska \\ Zakład Patologii i Rehabilitacji Mowy, Wydział Nauk o Zdrowiu \\ Uniwersytet Medyczny w Lublinie
}

DOI: https://doi.org/10.20883/pielpol.2018.3

\section{STRESZCZENIE}

Wstęp i cel. Obserwuje się w ostatnim czasie duże zmiany w obrębie postrzegania roli pacjenta, który z biernego odbiorcy świadczeń zdrowotnych przyjął postawę klienta, opiniującego i oceniającego realizowane usługi. Celem pracy było określenie wpływu wybranych czynników na poziom satysfakcji pacjentów makroregionu lubelskiego ze świadczeń lekarza specjalisty.

Materiał i metody. Grupę badaną stanowiło 144 pacjentów poradni udzielających specjalistycznych usług medycznych. Posłużono się metodą sondażu diagnostycznego, techniką ankietową. Narzędziem badawczym był autorski kwestionariusz służący do oszacowania stopnia zadowolenia ze świadczeń specjalistycznej opieki zdrowotnej. Do analizy materiału badawczego wykorzystano program SAS Enterprise Guide. Przyjęto poziom istotności $\mathrm{p}<0,05$. Posłużono się testami chi ${ }^{2}$ Pearsona, $t$-studenta i r-Spearmana.

Wyniki. Zadowolenie ze świadczeń specjalistycznej opieki zdrowotnej determinowane było stosunkiem lekarza do pacjenta, reakcją lekarza na zgłaszane przez pacjenta potrzeby i prośby, oceną poświęconego pacjentowi czasu i uwagi, skutecznością porady. Na poziom satysfakcji nie wpływał rodzaj wizyty.

Wnioski. Na zadowolenie pacjentów wpływa wiele różnych elementów. Spełnianie oczekiwań pacjentów rzutuje na jakość usług zdrowotnych, niosąc za sobą szereg pozytywnych konsekwencji.

SŁOWA KLUCZOWE: satysfakcja, jakość, specjalistyczna opieka zdrowotna, pacjenci.

\section{Wprowadzenie}

Obserwuje się w ostatnim czasie duże zmiany w obrębie postrzegania roli pacjenta, który z biernego odbiorcy świadczeń zdrowotnych przyjął postawę klienta, opiniującego i oceniającego realizowane usługi [1]. Dlatego też „(...) ocena zadowolenia pacjentów ze świadczeń wymaga wciąż nowych opracowań teoretycznych i empirycznych wyjaśnień” [2]. „Dokonanie oceny jakości świadczonych usług medycznych jest zadaniem

\begin{abstract}
Introduction and aim. Changes in the perception of the patient's role, who, from a passive recipient of health care benefits, has become an opinionated customer, evaluating the performance of service have been observed recently. The aim of the study was to assess the influence of selected factors on Lublin macroregion residents' level of satisfaction with services of a specialized doctor. Material and methods. 144 patients using the services of specialist clinics were the research group. A diagnostic poll method, which is a survey technique, was used when conducting this study. An authorial questionnaire was the research tool. Its purpose was to assess the patients' level of satisfaction with medical services. SAS Enterprise Guide software was used to analyze the gathered data. Statistical significance of $p<0.05$ was assumed. chi $^{2}$ Pearson, t-student and r-Spearman tests were used.

Results. Patients' satisfaction with medical services was defined by the doctor's approach towards the patient, the doctor's reaction to the patient's requests and needs, time and attention dedicated to the patient and effectiveness of the counsel. The type of the appointment did not influence the satisfaction level.

Conclusions. Many different factors affect patients' satisfaction with medical services. Reaching patients' expectations has an influence on the quality of medical services which entails a lot of positive consequences.
\end{abstract}

KEYWORDS: satisfaction, quality, specialized health care, patients.

trudnym. Wynika to z tego, że jakość jest inaczej pojmowana i ma inne znaczenie dla pacjenta, inne - dla osób świadczących usługi medyczne. Badając satysfakcję pacjentów, poznaje się ich subiektywne oceny, oparte na indywidualnym doświadczeniu, wymaganiach i oczekiwaniach" [3].

Trela twierdzi, że: „Pacjenci coraz częściej oczekują indywidulanego podejścia standaryzacji pracy, przewidywalności, stabilności, bezpieczeństwa opieki oraz 
szybszego dostępu do usług zdrowotnych. Wszystko to wpływa na zadowolenie pacjenta, czyli na satysfakcję z jakości oferowanych usług" [4]. Świadczeniobiorcy usług medycznych dużą wagę przywiązują do fachowości, profesjonalizmu, kompetencji, zaangażowania w wykonywaną pracę, sumienności i rzetelności personelu. Bardzo cenioną cechą jest także umiejętność właściwego i skutecznego komunikowania się z pacjentem, zrozumiałe wytłumaczenie przebiegu choroby oraz zastosowanego leczenia [5].

\section{Cel pracy}

Głównym celem badań było określenie wpływu wybranych czynników na poziom satysfakcji pacjentów makroregionu lubelskiego ze świadczeń lekarza specjalisty.

\section{Materiał i metody}

Grupę badaną stanowiło 144 pacjentów poradni udzielających specjalistycznych świadczeń: NZOZ Terapia Kuracja Przychodnia Specjalistyczna w Radzyniu Podlaskim, NZOZ Przychodnia Specjalistyczna Bio-Medical w Lublinie. Zdecydowaną większość $(78 \%, n=112)$ respondentów stanowiły kobiety. Badani reprezentowali grupy wiekowe: do 20 lat $(22 \%, n=31), 21-35$ lat $(42 \%$, $n=60), 36-50$ lat $(17 \%, n=25)$, ponad 50 lat $(19 \%, n=28)$, przy czym średnia wieku wynosiła 33,97 roku. Najmłodszy badany miał 15 lat, a najstarszy liczył 86 lat. Blisko połowa $(46 \%, n=67)$ respondentów posiadała wyższe wykształcenie. Pozostałą część badanej grupy stanowiły osoby z wykształceniem średnim $(33 \%, n=47)$, podstawowym $(11 \%, n=16)$, zawodowym $(10 \%, n=14)$. Aż 76\% ( $n=109)$ ankietowanych mieszkało w mieście.

Przeprowadzając badania, posłużono się metodą sondażu diagnostycznego, techniką ankietową. Narzędziem badawczym był autorski kwestionariusz służący do oszacowania stopnia zadowolenia ze świadczeń specjalistycznej opieki zdrowotnej; respondenci dokonywali subiektywnej oceny lekarza specjalisty. Kwestionariusz poruszał kwestie dotyczące stosunku lekarza do pacjenta, skuteczności uzyskanej w ramach wizyty porady lekarskiej, otwartości na zgłaszane przez chorego prośby i potrzeby, poświęconego czasu i uwagi, rodzaju wizyty. Narzędzie opatrzono metryczką z pytaniami o czynniki socjodemograficzne. Analizy materiału badawczego dokonano przy użyciu programu SAS Enterprise Guide. Przyjęto poziom istotności $p<0,05$, wskazujący na istotne statystycznie różnice bądź zależności. Posłużono się testami chi ${ }^{2}$ Pearsona, t-studenta i r-Spearmana.

\section{Wyniki}

Przeprowadzona analiza wykazała wysoce istotną statystycznie zależność między stosunkiem lekarza do pacjenta ( $p<0,0001)$, oceną reakcji lekarza na zgłaszane przez pacjenta potrzeby i prośby $(p<0,0001)$ a zadowoleniem ze świadczeń specjalistycznej opieki zdrowotnej. Zaobserwowano, iż wraz z bardziej pozytywnym nastawieniem lekarza do chorego i realizacją w wyższym stopniu potrzeb pacjentów rósł odsetek osób usatysfakcjonowanych z usług medycznych. Ankietowani pozytywnie oceniający podejście lekarza aż w $73 \%$ byli zadowoleni ze świadczeń. Największy poziom zadowolenia wykazywały osoby, których potrzeby urzeczywistniono w pełni (80\%). Stanowczo nieusatysfakcjonowani byli badani, których tylko niektóre prośby zostały spełnione (73\%). Ponadto uzyskano wysoce istotną statystycznie zależność między oceną poświęconego pacjentowi czasu i uwagi $(p<0,0001)$, skutecznością porady $(p<0,0001)$ a zadowoleniem ze świadczeń specjalistycznej opieki zdrowotnej. Badani, którzy postrzegali czas i uwagę poświęconą im podczas wizyty lekarskiej jako wystarczające, deklarowali znacznie częściej satysfakcję z usług (73\%). Na niezadowolenie ze świadczeń medycznych wskazywały przeważnie osoby uważające czas trwania usługi i uwagę lekarza za niewystarczające (89\%). Wszystkie osoby, zdaniem których uzyskana porada była nieskuteczna, były nieusatysfakcjonowane z usługi. Wśród badanych, którzy uzyskali poradę będącą celem wizyty, zadowolenie deklarowała większość grupy (84\%). Brak istotnej statystycznie zależności między rodzajem wizyty a zadowoleniem ze świadczeń specjalistycznej opieki zdrowotnej ( $p=0,7886)$. Nieznacznie częściej usatysfakcjonowane z usług medycznych były osoby odbywające wizytę prywatną (Tabela 1).

Tabela 1. Zależności między stosunkiem lekarza do pacjenta, reakcją na zgłaszane przez pacjenta potrzeby i prośby, oceną poświęconego pacjentowi czasu i uwagi, rodzajem wizyty, skutecznością porady a zadowoleniem ze świadczeń specjalistycznej opieki zdrowotnej Table 1. Dependences between the doctor's attitude to the patient, the doctor's reaction to the needs and requests reported by the patient, assessment of the time and attention devoted to the patient, type of the appointment, effectiveness of recommendations, and satisfaction with services of specialized health care

\begin{tabular}{|c|c|c|c|c|}
\hline \multirow[t]{3}{*}{$\begin{array}{l}\text { Zmienna/ } \\
\text { Variable }\end{array}$} & \multicolumn{4}{|c|}{$\begin{array}{c}\text { Zadowolenie ze świadczeń specjali- } \\
\text { stycznej opieki zdrowotnej/Satisfaction } \\
\text { with the services of specialized health } \\
\text { care }\end{array}$} \\
\hline & \multicolumn{2}{|c|}{ tak/yes } & \multicolumn{2}{|c|}{ nie/no } \\
\hline & $\mathrm{n}$ & $\%$ & $\mathrm{n}$ & $\%$ \\
\hline \multicolumn{5}{|c|}{ Stosunek lekarza do pacjenta/Doctor's attitude to the patient } \\
\hline pozytywny/positive & 87 & 73 & 32 & 27 \\
\hline negatywny/negative & 6 & 24 & 19 & 76 \\
\hline \multicolumn{5}{|c|}{$\begin{array}{c}\text { Analiza chi }{ }^{2} \text { Pearsona/Chi Pearson's analysis: } \\
\text { DF }=1, \text { chi-sq }=21,7833, p<0,0001\end{array}$} \\
\hline \multicolumn{5}{|c|}{$\begin{array}{l}\text { Reakcja lekarza na zgłaszane przez pacjenta potrzeby i prośby/Doctor's } \\
\text { reaction to the needs and requests reported by the patient }\end{array}$} \\
\hline tak, na wszystkie/yes, to all & 68 & 80 & 17 & 20 \\
\hline tak, na niektóre/yes, to some & 22 & 46 & 26 & 54 \\
\hline tylko na niektóre/only some & 3 & 27 & 8 & 73 \\
\hline
\end{tabular}




\begin{tabular}{|c|c|c|c|c|}
\hline \multicolumn{5}{|c|}{$\begin{array}{l}\text { Analiza chi }{ }^{2} \text { Pearsona/Chi Pearson's analysis: } \\
\text { DF=2, chi-sq=22,9045, } p<0,0001\end{array}$} \\
\hline \multicolumn{5}{|c|}{$\begin{array}{l}\text { Poświęcenie pacjentowi czasu i uwagi/ } \\
\text { Devoting time and attention to the patient }\end{array}$} \\
\hline tak, raczej tak/yes or rather yes & 91 & 73 & 34 & 27 \\
\hline nie, raczej nie/not or rather not & 2 & 11 & 17 & 89 \\
\hline \multicolumn{5}{|c|}{$\begin{array}{c}\text { Analiza chi }{ }^{2} \text { Pearsona/Chi Pearson's analysis: } \\
\text { DF }=1, \text { chi-sq }=27,9629, p<0,0001\end{array}$} \\
\hline \multicolumn{5}{|c|}{ Rodzaj wizyty/Type of the appointment } \\
\hline $\begin{array}{l}\text { w ramach umowy NFZ I } \\
\text { under the contract with NHF }\end{array}$ & 73 & 64 & 41 & 36 \\
\hline prywatnie/privately & 20 & 67 & 10 & 33 \\
\hline \multicolumn{5}{|c|}{$\begin{array}{l}\text { Analiza chi }{ }^{2} \text { Pearsona/Chi Pearson's analysis: } \\
\qquad D F=1, \text { chi-sq }=0,0719, p=0,7886\end{array}$} \\
\hline \multicolumn{5}{|c|}{ Skuteczność porady/Effectiveness of recommendations } \\
\hline tak/yes & 64 & 84 & 12 & 16 \\
\hline raczej tak/rather yes & 29 & 47 & 32 & 53 \\
\hline raczej nie/rather not & 0 & 0 & 6 & 100 \\
\hline nie/no & 0 & 0 & 1 & 100 \\
\hline
\end{tabular}

$\mathrm{n}$ - liczebność/number, \% - odsetek/percentage, DF - stopnie swobody/degrees of freedom, $\mathrm{p}-$ istotność statystyczna/statistical significance, chi-sq - wynik testu $\mathrm{chi}^{2} /$ chi $^{2}$ test results

Źródło: opracowanie własne

Source: author's own analysis

Uzyskane wyniki poddano dodatkowej analizie z wykorzystaniem testu t-studenta, który wykazał istotną statystycznie różnicę $w$ zadowoleniu ze świadczeń specjalistycznej opieki zdrowotnej między wszystkimi analizowanymi grupami $(p<0,05)$ prócz tej $z$ podziałem na rodzaj wizyty $(p=0,8133)$. Średnia ocena zadowolenia $z$ oferowanych usług była znacznie wyższa u:

- osób pozytywnie oceniających podejście lekarza do pacjenta $(M=3,86)$ niż wśród badanych o negatywnej opinii ( $M=2,96)$;

- osób, zdaniem których lekarz reagował na wszystkie zgłaszane potrzeby i prośby $(M=3,96)$, niż wśród chorych, których tylko wybrane potrzeby i prośby spełniono $(M=3,32)$;

- osób, którym lekarz poświęcił wystarczająco dużo czasu i uwagi ( $M=3,85$ ), niż wśród badanych, zdaniem których długość wizyty i ilość uwagi były zbyt małe ( $M=2,74)$;

- osób, które w pełni lub częściowo uzyskały poradę będącą celem wizyty ( $M=3,77)$, niż wśród pacjentów, którzy takiej porady nie uzyskali $(M=2,29)$ (Tabela 2).
Tabela 2. Różnice w zadowoleniu ze świadczeń specjalistycznej opieki zdrowotnej względem stosunku lekarza do pacjenta, reakcji na zgłaszane przez pacjenta potrzeby i prośby, oceny poświęconego pacjentowi czasu i uwagi, rodzaju wizyty, skuteczności porady

Table 2. Differences in satisfaction with services of specialized health care in relation to the doctor's attitude to the patient, doctor's reaction to the needs and requests reported by the patient, assessment of the time and attention devoted to the patients, the type of the appointment, effectiveness of recommendations

\begin{tabular}{|c|c|c|c|c|c|c|c|}
\hline \multirow{2}{*}{\multicolumn{2}{|c|}{$\begin{array}{l}\text { Zadowolenie ze świadczeń } \\
\text { specjalistycznej opieki } \\
\text { zdrowotnej/Satisfaction } \\
\text { with services of specialized } \\
\text { health care }\end{array}$}} & \multirow[t]{2}{*}{$\mathrm{n}$} & \multirow[t]{2}{*}{ M } & \multirow[t]{2}{*}{ SD } & \multicolumn{3}{|c|}{$\begin{array}{c}\text { Analiza test } \\
\text { t-studenta/Analysis of } \\
t \text {-student test }\end{array}$} \\
\hline & & & & & DF & $t$ & $p$ \\
\hline $\begin{array}{c}\text { Stosunek } \\
\text { lekarza do } \\
\text { pacjenta/ } \\
\text { Doctor's } \\
\text { attitude to the } \\
\text { patient }\end{array}$ & $\begin{array}{l}\text { pozytywny/ } \\
\text { positive } \\
\text { negatywny/ } \\
\text { negative }\end{array}$ & 119 & 2,96 & 0,79 & 33,746 & $-5,21$ & $<0,0001$ \\
\hline $\begin{array}{l}\text { Reakcja } \\
\text { lekarza na } \\
\text { zgłaszane } \\
\text { przez } \\
\text { pacjenta } \\
\text { potrzeby } \\
\text { i prośbyl } \\
\text { Doctor's } \\
\text { reaction the } \\
\text { needs and } \\
\text { requests } \\
\text { reported by } \\
\text { the patient }\end{array}$ & $\begin{array}{c}\text { tak, na } \\
\text { wszystkie/ } \\
\text { yes, to all } \\
\\
\text { tak, na } \\
\text { niektóre } \\
\text { lub tylko na } \\
\text { niektóre/ } \\
\text { yes, to some } \\
\text { or only some }\end{array}$ & 85 & 3,96 & 0,64 & 96,664 & $-4,64$ & $<0,0001$ \\
\hline $\begin{array}{l}\text { Poświęcenie } \\
\text { pacjentowi } \\
\text { czasu } \\
\text { i uwagi/Dedi- } \\
\text { cating time and } \\
\text { attention to the } \\
\text { patient }\end{array}$ & $\begin{array}{c}\text { tak, raczej tak/ } \\
\text { yes or rather } \\
\text { yes } \\
\text { nie, raczej nie/ } \\
\text { not or rather } \\
\text { not }\end{array}$ & $\begin{array}{l}125 \\
19\end{array}$ & 3,85 & 0,73 & 23,937 & $-6,14$ & $<0,0001$ \\
\hline $\begin{array}{l}\text { Rodzaj } \\
\text { wizyty/Type } \\
\text { of appoint- } \\
\text { ment }\end{array}$ & $\begin{array}{l}\text { w ramach } \\
\text { umowy NFZI } \\
\text { under the } \\
\text { contract with } \\
\text { NHF } \\
\text { prywatnie/ } \\
\text { privately }\end{array}$ & 114 & 3,73 & 0,91 & 142 & 0,24 & 0,8133 \\
\hline $\begin{array}{l}\text { Skuteczność } \\
\text { porady/The } \\
\text { effectiveness } \\
\text { of recommen- } \\
\text { dations }\end{array}$ & $\begin{array}{l}\text { tak, raczej tak/ } \\
\text { yes, rather yes } \\
\text { nie, raczej nie/ } \\
\text { no, rather not }\end{array}$ & 137 & 3,77 & 0,76 & 6,6468 & $-5,08$ & 0,0017 \\
\hline
\end{tabular}

$\mathrm{n}$ - liczebność/number, $\mathrm{M}$ - średnia/average, SD - odchylenie standardowe/ standard deviation, DF - stopnie swobody/degrees of freedom, $\mathrm{p}$ - istotność statystyczna/statistical significance, $\mathrm{t}$ - wynik testu $\mathrm{t}$-studenta/t-student test results

Źródło: opracowanie własne

Source: author's own analysis

Wyżej przedstawione wyniki potwierdza rezultat testu r-Spearmana, który wskazuje na występowanie istotnej statystycznie korelacji między stosunkiem lekarza do pacjenta $(p<0,0001)$, skutecznością uzyskanej porady $(p<0,0001)$ a zadowoleniem ze świadczeń spe- 
cjalistycznej opieki zdrowotnej. Uzyskane związki były silne i dodatnie ( $r>0$ oraz $|r|<0,5)$, co oznacza, że wraz ze wzrostem skuteczności udzielonej przez lekarza porady i bardziej przychylną oceną nastawienia lekarza do pacjenta rosła satysfakcja z usług medycznych. Uzyskano istotną statystycznie korelację między reakcją lekarza na zgłaszane przez pacjenta potrzeby i prośby ( $p<0,0001$ ), oceną poświęconego pacjentowi czasu i uwagi $(p<0,0001)$ a zadowoleniem ze świadczeń specjalistycznej opieki zdrowotnej. Uzyskane związki były słabe i dodatnie ( $r>0$ oraz $|r|<0,5)$, co oznacza, że wraz z większą reakcją na prośby i potrzeby pacjenta i bardziej przychylną oceną poświęconego pacjentowi przez lekarza czasu i uwagi rosło zadowolenie ze świadczeń specjalistycznej opieki zdrowotnej (Tabela 3).

Tabela 3. Analiza korelacji między stosunkiem lekarza do pacjenta, reakcją na zgłaszane przez pacjenta potrzeby i prośby, oceną poświęconego pacjentowi czasu i uwagi, skutecznością porady a zadowoleniem ze świadczeń specjalistycznej opieki zdrowotnej

Table 3. Analysis of the correlation between the doctor's attitude to the patient, doctor's reactions on the needs and requests reported by the patient, assessment of the time and attention devoted to the patient, the effectiveness of recommendations, and satisfaction with the services of specialized health care

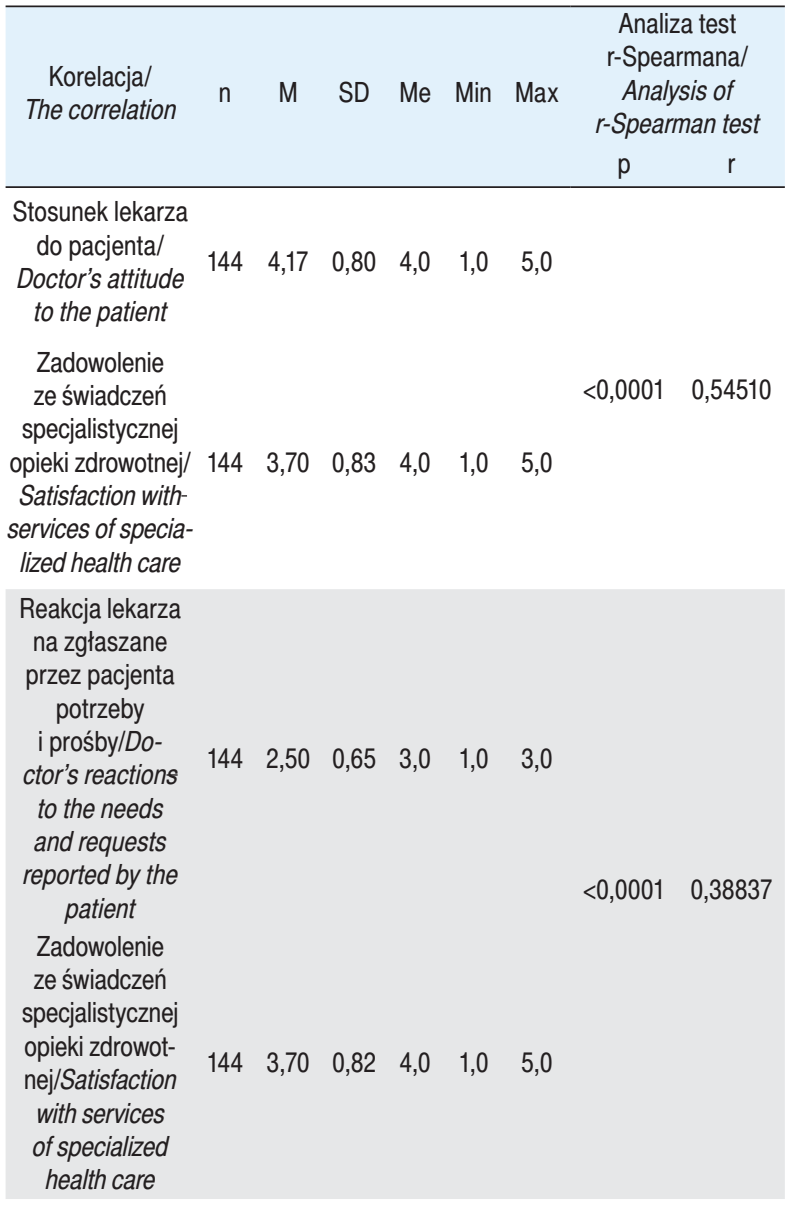

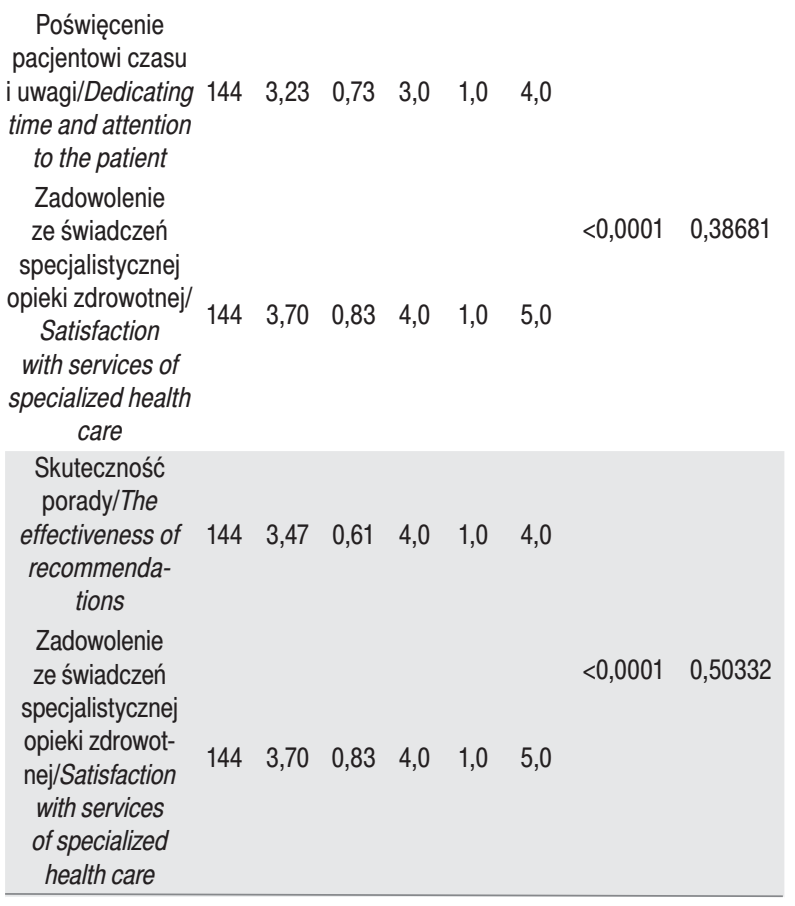

$\mathrm{n}$ - liczebność/number, M - średnia/average, SD - odchylenie standardowe/ standard deviation, Me - mediana/median, Min - wartość minimalna/minimum value, Max - wartość maksymalna/maximum value, $\mathrm{p}$ - istotność statystyczna/statistical significance, $\mathrm{r}$ - współczynnik korelacji/correlation coefficient

Źródło: opracowanie własne

Source: author's own analysis

\section{Dyskusja}

Każdy pacjent wymaga innego, indywidualnego podejścia. Dlatego niezmiernie ważnym aspektem wpływającym na zadowolenie z jakości usług medycznych jest ilość czasu poświęcanego świadczeniobiorcom przez personel medyczny. Przeprowadzone badania wykazały, że osoby postrzegające czas i uwagę przeznaczone im przez lekarza jako wystarczające przejawiają wyższy poziom zadowolenia ze świadczeń. Pozytywne opinie na temat wymiaru czasu poświęconego pacjentom przez lekarza miało ogólnie $73 \%$ badanych. Zbliżone rezultaty uzyskali Smolińska i wsp. Ankietowani przez zespół w 84\% pozytywnie ocenili ilość czasu, jaką personel lekarski przeznaczał chorym [3]. W badaniach Raduj i wsp. zdecydowana większość pacjentów (93\%) oceniła ilość oferowanego przez lekarzy czasu na poziomie dobrym [6]. Jak wykazały wyniki badań przeprowadzonych przez Kemicer-Chmielewską i wsp., ponad połowa $(57,8 \%)$ ankietowanych była zadowolona z czasu trwania wizyty lekarskiej [7]. Zaś na jego niedostatek narzekali w dużej mierze respondenci w badaniach Szpringer i wsp. Pozytywnie kwestię tę oceniło $41,7 \%$ ankietowanych. Opinię pacjentów na temat ilości czasu poświęconego im przez lekarza determinował status zawodowy $(p=0,003)$. Najgorzej zagadnienie to 
oceniły osoby bezrobotne (71,5\%) [8]. Marcinów i Olejniczak oszacowali, iż 70\% wizyt lekarskich mieści się w przedziale 10-19 minut, przy czym aż 42\% ankietowanych przez nich pacjentów odpowiedziało, iż jest to czas niewystarczający [9]. Zdaniem Etier i wsp. satysfakcja pacjenta jest i nadal będzie ważnym determinantem działania systemu opieki zdrowotnej. Aż 94\% badanych pacjentów poradni ortopedycznych było zadowolonych z wizyty lekarskiej. Pozostali ankietowani wskazali na niedostateczną ilość poświęconego im czasu [10]. W badaniach Leźnickiej i wsp. czas poświęcony pacjentowi przez personel lekarski negatywnie oceniło 6,8\% badanych. Uczestnicy badania skarżyli się także na zbyt długi okres oczekiwania na przyjęcie do szpitala, gdyż za bardzo krótki uznało go tylko 33\% [11]. Warto także przytoczyć rezultaty z badań Skowron i wsp., którzy dowodzą, iż krótki czas oczekiwania na przyjęcie do szpitala wpływa pozytywnie na ocenę jakości podmiotu leczniczego. Aż 83\% respondentów było niezadowolonych z czasu oczekiwania na izbie przyjęć, a czas reakcji lekarzy na wezwanie negatywnie oceniło $37 \%$ badanych [12]. Long i wsp. podkreślają, iż bardzo istotne jest zapewnienie pacjentom wysokiej jakości świadczeń, które będą wpływać na ich usatysfakcjonowanie i prawdopodobieństwo polecenia usług innym osobom. Według przeprowadzonej przez zespół analizy na uzyskanie dobrego wrażenia w oczach pacjentów wpływają ilość czasu spędzonego u świadczeniodawcy, łatwość planowania przebiegu terapii, uprzejmość personelu [13].

Kolejnym aspektem rzutującym w dużej mierze na ocenę specjalistycznej opieki medycznej jest trafność postawionej diagnozy. W badaniach własnych wystąpiła wysoce istotna statystycznie zależność między skutecznością porady a zadowoleniem z usług lekarza specjalisty ( $p<0,0001)$. Osoby, zdaniem których uzyskana porada była nieskuteczna, były nieusatysfakcjonowane z usługi. Wśród badanych, którzy uzyskali poradę będącą celem wizyty, zadowolenie deklarowała większość grupy (84\%). Istotę tej kwestii podkreślają Moczydłowska i wsp. Ankietowani przez zespół pacjenci w największym stopniu oczekiwali od lekarza trafnej diagnozy, zdolności umiejętnego badania i kompetencji, aby był godny zaufania, rozsądny, bezinteresowny i okazujący szacunek. Zdaniem badaczy dobra opinia na temat personelu lekarskiego będzie skutkować u pacjentów zaufaniem do pracowników medycznych, traktowaniem ich jako ekspertów i stosowaniem się do zaleceń [14]. Można to stwierdzić także na podstawie rezultatów przeprowadzonych przez Waksmańską i wsp. badań, w których pacjenci bardzo dużą wage przykładali do zasobu fachowej wiedzy lekarzy $(86,4 \%)$ [15]. Z kolei w badaniach Grabskiej poziom wiedzy i posiadane specjalizacje ważne były tylko dla 29\% respondentów [16]. Zdaniem Puczkowskiej i wsp. najistotniejsze jest, by posiadany zasób specjalistycznej wiedzy umiejętnie wykorzystywać w praktyce [17]. Jak podkreślają Bilicka i wsp., owa wiedza niezbędna jest podczas wyjaśniania celowości działań podejmowanych w ramach procesu terapeutycznego pacjentowi i jego rodzinie [18]. Ankietowani przez Skowron i wsp. byli zdecydowanie zadowoleni ze sposobu przekazywania informacji dotyczących choroby i ewentualnych powikłań. Zdaniem $87 \%$ badanych lekarze okazywali wystarczające zainteresowanie pacjentem, zachowując kulturę i grzeczność (93\%). W opinii badaczy indywidualne podejście do pacjenta poprawia jakość usługi medycznej [12]. Zdaniem niewiele ponad połowy badanych przez Kemicer-Chmielewską i wsp. personel lekarski wykazał się umiejętnością aktywnego słuchania, delikatnością podczas badania, informował o nazwie rozpoznanej choroby, konieczności zgłaszania się na wizyty kontrolne [7]. Waszkiewicz i Białecka donoszą, iż tylko 46,7\% respondentów oceniło bardzo dobrze informacje udzielane przez personel medyczny, związane z przebiegiem wykonywanego badania i ryzykiem jego podjęcia. Pacjenci byli przeciętnie usatysfakcjonowani $z$ udzielonych informacji o sposobach leczenia i stanie zdrowia - diagnozie. Umiejętność aktywnego słuchania i relacje międzyludzkie, zwłaszcza okazywanie życzliwości i empatii personelu medycznego wobec pacjenta uznano za przeciętne [19]. Z kolei ankietowani w badaniach Leźnickiej i wsp. największe zastrzeżenia mieli do informowania pacjenta o jego prawach (25\%), skutkach ubocznych przyjmowanych lekarstw (26\%), sposobach leczenia (7\%), ryzyku związanym z podejmowanym leczeniem (11\%) czy przebiegu operacji (10\%). Za silnie problematyczne postrzegali sytuacje, w których pracownicy wygłaszali sprzeczne ze sobą opinie dotyczące stanu zdrowia, terapii i rozmawiali o pacjencie w obecności osób trzecich [11]. Ankietowani przez Weidemann i wsp. pacjenci kardiologiczni byli bardzo zadowoleni z opieki lekarskiej. Analiza wykazała pięć głównych determinantów owej satysfakcji: omawianie z pacjentem wyników leczenia, zindywidualizowana opieka medyczna, udzielanie jasnych odpowiedzi na pytania, wykazywanie empatii, uprzejmości, dobroci, wyposażenie sal. Badacze podkreślają wagę komunikacji i stosunku pracowników służby zdrowia do chorych [20]. Także Bible i wsp. są zdania, że na zadowolenie pacjentów wpływa wiele różnych elementów. Planowanie terapii, dostęp do parkingu, czas oczekiwania, ciągłość procesu leczenia, okazywanie empatii, dobra współpraca i komunikacja, uzyskiwanie wyjaśnień i informacji o stanie zdrowia były istotnie związane z ogólnym zadowoleniem zarówno z wizyty, jak i jakości opieki [21]. 
W ocenie badanych pacjentów bardzo ważnym czynnikiem rzutującym na poziom zadowolenia z opieki medycznej był stosunek lekarza do pacjenta, co potwierdza wysoce istotna statystycznie zależność. Zaobserwowano, że wraz z rosnącą pozytywną oceną podejścia lekarza wzrasta satysfakcja z oferowanych usług. Jak zauważa Krot, pacjenci prócz trafnej diagnozy oczekują od lekarzy zrozumienia, wsparcia, otuchy, umiejętności słuchania, akceptacji czyli szeroko pojętych umiejętności interpersonalnych [22]. Mielnicki-Błaszczak i wsp. za czynnik silnie determinujący stopień zadowolenia świadczeniobiorców usług medycznych uważają relacje lekarz - pacjent. Zdaniem badaczy trudności w uzyskaniu satysfakcjonujących relacji spowodowane są wadami w systemie opieki zdrowotnej. Mimo reformowania systemu ochrony zdrowia ciągle ocenia się go na niskim poziomie [23]. Blisko połowa badanych przez Leźnicką i wsp. podkreśliła znaczenie uważnego słuchania przez personel lekarski, zapewnienia intymności i wyrażania się w sposób zrozumiały dla pacjenta, które oceniono na przeciętnym poziomie [11]. Z kolei Mamos i Jeziorska analizowały opinie personelu medycznego na temat oferowanych przez niego świadczeń. Badani w stopniu dostatecznym ocenili czas poświęcany pacjentowi i szybkość reagowania na wezwania. Wskazali na problemy z organizacją i punktualnością, które w dużej mierze rzutują na jakość usług. Zaś wysoko ocenili komunikację z pacjentem [24], co należy uznać za zastanawiające, gdyż w opinii pacjentów to właśnie komunikacja, przepływ informacji uważane są za najsłabsze ogniwo systemu ochrony zdrowia. Łukasik i wsp. podkreślają, iż postawa personelu medycznego charakteryzująca się życzliwością, cierpliwością, zrozumieniem, fachową wiedzą medycyną, ale i znajomością psychologii i pedagogiki znacznie ogranicza przykre oraz stresujące doznania pacjentów [25]. Tak samo twierdzą De Salins i wsp., według których umiejętności interpersonalne personelu medycznego są najważniejszymi czynnikami satysfakcji z usług ambulatoryjnych. Na ogólną satysfakcję pacjentów dermatologicznych wpływały jakość życia, zainteresowanie lekarza problemem medycznym i zwrócenie uwagi na objawy, komfort podczas oczekiwania na usługe w poczekalni. Poprawa satysfakcji pacjentów może prowadzić do lepszego przestrzegania zaleceń lekarskich, a w konsekwencji - do lepszych wyników klinicznych [26].

Zauważono, iż na zadowolenie ze świadczeń specjalistycznej opieki zdrowotnej w sposób istotny wpływała ocena reakcji lekarza na zgłaszane przez pacjenta potrzeby i prośby $(p<0,0001)$. Zaobserwowano, iż wraz z rosnącą realizacją potrzeb pacjentów rosła satysfakcja z usług zdrowotnych. Największy poziom zadowolenia wykazywały osoby, których potrzeby urzeczywistniono w pełni (80\%). Stanowczo nieusatysfakcjonowani byli badani, których prośby tylko częściowo zostały spełnione (73\%). Także w badaniach Jachimowicz-Gaweł i wsp. pacjenci najwyższe oczekiwania mieli w odniesieniu do szybkości reagowania na potrzeby pacjentów, realizacji usług we wskazanym czasie. Najniższe zaś względem liczby miejsc parkingowych i siedzących w przychodni, godzin funkcjonowania przychodni czy estetycznego wyglądu pomieszczeń [27]. Dla pacjentów ankietowanych przez Wolniaka najistotniejszymi czynnikami wpływającymi na poziom zadowolenia z opieki medycznej były bezpieczeństwo przeprowadzania usługi i reakcja na zgłaszane przez nich prośby, które niestety były najgorzej ocenionymi obszarami. Zdaniem badacza pracownicy medyczni obciążeni są nadmiarem zadań, w konsekwencji czego napotykają na problemy z ukierunkowaniem swych wysiłków na konkretnego pacjenta. Nie zawsze wykonują terminowo usługi i reagują na pytania i problemy pacjentów. Przyczyną takiego stanu jest zbyt mała liczba pracowników, co prowadzi do przeciążenia zadaniami [28].

\section{Wnioski}

1. Zadowolenie ze świadczeń specjalistycznej opieki zdrowotnej determinowane było stosunkiem lekarza do pacjenta, jego reakcją na zgłaszane przez pacjenta potrzeby i prośby, oceną poświęconego pacjentowi czasu i uwagi oraz skutecznością porad.

2. Na poziom satysfakcji ze świadczeń specjalistycznej opieki zdrowotnej nie wpływał rodzaj wizyty. Nieznacznie częściej usatysfakcjonowane z usług medycznych były osoby odbywające wizyte prywatną.

\section{Piśmiennictwo}

1. Marcinowicz L. Metody badania. Satysfakcja pacjenta. Mag Piel Położ. 2005; 5: 10-11.

2. Naskręt K, Biskupska M, Niewiadomski TJ, Stachowska M. Zadowolenie pacjenta ze świadczeń lekarza specjalisty - badanie wstępne. Hygeia. 2014; 49(3): 617-623.

3. Smolińska A, Marciniak M, Ślusarz R, Królikowska A, Jabłońska R, Książkiewicz B. Poziom satysfakcji z usług medycznych na oddziale neurologii. Udar Mózgu. 2008; 10(2): 70-82.

4. Trela A. Zarządzanie jakością w placówce medycznej. Warszawa: Wiedza i Praktyka; 2014. 13.

5. Juszczyk G, Koperny M, Kuźma M, Czerw A, Strzępek $Ł$. Oczekiwania pacjentów wobec opieki szpitalnej przy wykorzystaniu portalu społecznościowego. J Health Sci. 2014; 4(15): 116-126.

6. Raduj J, Indulska I, Anczewska M, Lechowicz W, Pałyska M, Prot K. Jakość usług medycznych w opinii pacjentów wybranych oddziałów psychiatrycznych. Post Psychiatr Neurol. 2005; 14(4): 293-298.

7. Kemicer-Chmielewska E, Rotter I, Kotwas A, Koziarska D, Karakiewicz B. Ocena jakości usług medycznych przez pacjentów z uwzględnieniem wybranych zmiennych socjodemograficznych. Ann Acad Med Stetin. 2013; 59(2): 143-146. 
8. Szpringer M, Chmielewski J, Kosecka J, Sobczyk B, Komendacka O. Poziom satysfakcji pacjenta jako jeden z aspektów jakości opieki medycznej. Med Ogólna Nauki Zdr. 2015; 21(2): 132-137.

9. Marcinów K, Olejniczak D. Opinie i oczekiwania pacjentów względem systemu opieki zdrowotnej. Med Rodz. 2011; 4: 99-104.

10. Etier BE, Orr SP, Antonetti J, Thomas SB, Theiss SM. Factors impacting Press Ganey patient satisfaction scores in orthopedic surgery spine clinic. J Spine. 2016; 16(11): 1285-1289.

11. Leźnicka M, Warunek A, Hartwich E, Kryn P. Ocena satysfakcji pacjenta z usług świadczonych w stacjonarnej opiece zdrowotnej w województwie kujawsko-pomorskim. Hygeia. $2014 ;$ 49(4): 787-792.

12. Skowron K, Mocigemba A, Osial P. Jakość obsługi pacjenta we współczesnym podmiocie leczniczym na przykładzie Samodzielnego Publicznego Szpitala Klinicznego Nr 6 Śląskiego Uniwersytetu Medycznego w Katowicach Górnośląskie Centrum Zdrowia Dziecka im. Jana Pawła II. Zesz Nauk Politechniki Śląskiej. Seria: Organizacja i Zarządzanie. 2016; 1(33): 131-144.

13. Long C, Tsay EL, Jacobo SA, Popat R, Singh K, Chang RT. Factors Associated with Patient Press Ganey Satisfaction Scores for Ophthalmology Patients. Ophthalmology. 2016; 123(2): 242-247.

14. Moczydłowska A, Krajewska-Kułak E, Kózka M, Bielski K. Oczekiwania chorych wobec personelu lekarskiego. Hygeia. 2014; 49(1): 142-151.

15. Waksmańska W, Łukasik R, Gawlik K, Makowska-Songin J. Oczekiwania rodzin pacjentów a postawy personelu medycznego - analiza na przykładzie Szpitala Pediatrycznego w Bielsku-Białej. Probl Piel. 2012; 20(1): 70-75.

16. Grabska K, Stefańska W. Sylwetka zawodowa pielęgniarki w opinii pacjentów. Probl Piel. 2009; 17(1): 8-12.

17. Puczkowska E, Krajewska-Kułak E, Jankowiak B, Wasilewska A, Kułak W. Ocena stopnia zadowolenia matek z opieki na oddziale pediatrycznym. Pediatr Pol. 2005; 80(3): 294-298.

18. Bilicka D, Korbińska M, Popow A, Szewczyk M. Oczekiwania rodziców względem opieki pielęgniarskiej nad dzieckiem w warunkach szpitalnych. Piel Chir Angiol. 2009; 1: 20-25.

19. Waszkiewicz A, Białecka B. Kształtowanie usług medycznych na podstawie oceny i odczucia pacjenta. Zesz Nauk Politechniki Śląskiej. Seria: Organizacja i Zarządzanie. 2012; 63a: 259-273.

20. Weidemann RR, Schönfelder T, Klewer J, Kugler J. Patient satisfaction in cardiology after cardiac catheterization: Ef- fects of treatment outcome, visit characteristics, and perception of received care. Herz. 2016; 41(4): 313-319.

21. Bible JE, Shau DN, Kay HF, Cheng JS, Aaronson OS, Devin CJ. Are Low Patient Satisfaction Scores always Due to the Provider? Determinants of Patient Satisfaction Scores During Spine Clinic Visits. J Spine. 2016; DOI: 10.1097/ BRS.0000000000001453.

22. Krot K. Jakość i marketing usług medycznych. Warszawa: Wolters Kluwer Business; 2008. 59-61.

23. Mielnicki-Błaszczak M, Zioło A, Kawiak-Jawor E. Relacja pacjent - lekarz od paternalizmu do partnerstwa. Zdr Publ. 2011; 121(1): 95-98.

24. Mamos AR, Jeziorska M. Jakość usług medycznych w ocenie personelu zakładu opieki zdrowotnej - cz. II. Ogólnopol Prz Med. 2012; 12: 61-64.

25. Łukasik R, Waksmańska W, Gawlik K. Aspekty pobytu rodziców wraz z dzieckiem w szpitalu. Probl Piel. 2010; 18(2): 169-175.

26. De Salins CA, Brenaut E, Misery L, Roguedas-Contios AM. Factors influencing patient satisfaction: assessment in outpatients in dermatology department. J Eur Acad Dermatol Venereol. 2016; 30(10): 1823-1828.

27. Jachimowicz-Gaweł D, Leksowski K, Bajerska J. Analiza oczekiwań pacjentów w wybranych aspektach oceny jakości usług zdrowotnych (infrastruktura zewnętrzna, niezawodność, wymiar materialny, warunki bytowe). Pr Nauk Uniw Ekon Wroc. 2015; 410: 180-193.

28. Wolniak R. Pomiar oczekiwanej i postrzeganej jakości w usługach medycznych. Współcz Zarz. 2010; (2): 128-139.

Artykuł przyjęty do redakcji: 04.04.2017

Artykuł przyjęty do publikacji: 30.06.2017

Źródło finansowania: Praca nie jest finansowana z żadnego źródła. Konflikt interesów: Autorzy deklarują brak konfliktu interesów.

\author{
Adres do korespondencji: \\ Olga Dąbska \\ ul. Stanisława Staszica 4-6 \\ 20-081 Lublin \\ tel.: 814486792 \\ e-mail: olga.dabska@umlub.pl \\ Zakład Patologii i Rehabilitacji Mowy, Wydział Nauk o Zdrowiu \\ Uniwersytet Medyczny w Lublinie
}

